\title{
Lihaluujauho ohran ja kauran lannoitteena
}

Jukka Kivelä'ㅣ Juha Helenius ${ }^{1}$, Lin Chen ${ }^{1}$ ja Arjo Kangas ${ }^{2}$

1) Helsingin yliopisto, maataloustieteiden laitos, Latokartanonkaari 5-7, 00014 Helsingin yliopisto

2) Maa- ja elintarviketalouden tutkimuskeskus, Alapääntie 104, 61400 Ylistaro

\section{Tiivistelmä}

Väkilannoitteiden tuottaminen perustuu fossiilisen energian käyttöön. Erityisesti väkilannoitteiden sisältämän typen valmistamien vaatii runsaasti uusiutumatonta energiaa. Toisaalta väkilannoitteissa hyödynnetään myös erittäin rajallisia mineraalisia esiintymiä, kuten apatiittia fosforin lähteenä. Väkilannoitteiden käyttöä ei voida pitää kestävän kehityksen tavoitteiden mukaisena.

Väkilannoitteita täydentäviä tai niitä korvaavia orgaanisia lannoitteita on kehitetty viime vuosina. Orgaaniset lannoitteet perustuvat teollisessa tuotannossa ja yhdyskuntien toiminnoissa syntyvien jäteaineiden tai sivutuotteiden hyödyntämiseen. Kiinnostus orgaanisiin lannoitteisiin on viime vuosina ollut suurta, myös siksi että niiden avulla voidaan parantaa ruokajärjestelmän ravinnekiertoa. Markkinoille on esimerkiksi tullut jätevedenpuhdistamojen kehittämiä lannoitteita. Orgaanisten lannoitetuotteiden tarve korostuu luonnonmukaista kasvinviljelyä harjoittavilla tiloilla. Koska luomuviljelyssä ei sallita väkilannoitteita, on erityisesti karjattomilla tiloilla tarvetta saada käyttökelpoisia eloperäisiä lannoitteita, jotka korvaavat satojen mukana poistuneita ravinteita.

Lihaluujauho, jota muodostuu teurastamoteollisuuden eläinperäisten sivutuotteiden käsittelyn yhteydessä, sisältää merkittäviä määriä kasvinravinteita. Keskimääräiset arvot ovat 8 \% N, 5 \% P, 1 \% K ja yli $10 \% \mathrm{Ca}$; näiden määrien perusteella lihaluujauho voisi hyvin toimia lannoitteena. Lihaluujauhoa valmistetaan Suomessa noin 25000 tonnia vuodessa. EU-maissa lihaluujauhon käyttö orgaanisena lannoitteena sallittiin EY asetuksella No 181/2006.

MTT:n Etelä-Pohjanmaan tutkimusasemalla Ylistarossa toteutetuissa kokeissa vuosina 2000-2003 lihaluujauhoa verrattiin tavalliseen väkilannoitteeseen tutkimuslohkolla, jossa käytettiin tavanomaisen viljelyn menetelmiä. Lannoitteen testaamiseksi tehtiin kaksi täydellisten kerranteiden osaruutukoetta: kaksivuotinen lannoituskoe ohralla ja kolmivuotinen lannoituskoe kauralla. Kaurakoetta jatkettiin neljäntenä vuonna jälkivaikutuskokeena. Koetekijät olivat lannoitelaji ja typen määrä portaina. Väkilannoitteena, johon lihaluujauhoa verrattiin, käytettiin seoslannoitetta $(20 \%$ N, $3 \%$ P, ja $9 \%$ K). Typpiportaat olivat 60,90 ja 120 $\mathrm{kg} \mathrm{N} \mathrm{ha}^{-1}$. Lihaluujauholannoituksen satomäärä ei eronnut merkitsevästi väkilannoitteella saadusta millään typpilannoituksen tasolla. Kokonaissato nousi 120 kilon typpitasolla ohralla 4500 kiloon ja kauralla 5000 kiloon hehtaarilta, mitkä vastaavat samankaltaisissa viljelyolosuhteissa Suomessa saatavia keskimääräisiä satoja.

Lisäksi osoittautui, että lihaluujauho- ja väkilannoituksella ei ollut merkitsevää eroa viljan laatutekijöiden kannalta. Kokeessa määritellyt laatuominaisuudet olivat 1000 siemenen paino, hehtolitrapaino, valkuaispitoisuus ja valkuaissato. Koska lihaluujauhon N/P - suhde on pieni, fosforia kertyy maahan, kun lihaluujauhoa käytetään typpilannoitteena. Lihaluujauholannoituksen käyttömäärät tulee sovittaa tilan viljelykiertoon niin, että samalla voidaan saavuttaa myös ympäristönsuojelun tavoitteet. Työ on julkaistu vertaisarvioituna (Chen et al. 2011. Agric. Food Sci 20: 235-244).

Asiasanat: lihaluujauho, lannoitus, kierrätysravinteet 


\section{Johdanto}

Lihaluujauho on renderöintiteollisuuden tuote, joka sisältää noin $8 \%$ typpeä, $5 \%$ fosforia, $1 \%$ kaliumia ja $10 \%$ kalsiumia, riippuen raaka-aineesta. Lihaluujauhon valmistus aloitettiin teurastamojen sivutuotteiden käsittelemiseksi, ja sitä käytettiin alun perin tuotantoeläinten rehuna. Lihaluujauhon rehukäytön märehtijöille epäillään olleen syynä BSE-taudin (bovine spongiform encephalopathy) muodostumiseen (Brewer 1999). Lihaluujauhon rehukäyttö kiellettiin EU:n toimesta kokonaan vuonna 2000, ja samalla rajoitettiin voimakkaasti lihaluujauhon käyttöä lannoitteena (Werner 2003). Vuonna 2006 annettiin jäsenmaiden aloitteesta EY:n asetus 181/2006 (sivutuoteasetusta täydentävä asetus), jonka perusteella EU:n alueella jälleen sallittiin lihaluujauhon käyttö kasvinviljelyn lannoitteena.

Teollisen ekologian idean mukaisesti (Graedel 1996, Frosch ja Gallopoulos 1989) lihaluujauhon ravinteiden kierrättäminen takaisin ruokajärjestelmään tehostaisi luonnonvarojen käyttöä. Vuosittain EU:n alueella tuotetaan lihaluujauhoa yli 3 miljoonaa tonnia (Werner 2003). Ravinteiden kokonaismäärä tässä 15 EU:n alueen maassa kertyvässä lihaluujauhossa on noin $120 \times 10^{6} \mathrm{~kg} \mathrm{~N}$ ja $155 \times 10^{6} \mathrm{~kg} \mathrm{P}$ (Werner 2003). Suomessa muodostuu vuosittain yli $200 \times 10^{6}$ kiloa eläinperäisiä sivutuotteita (tuore paino, kosteuspitoisuus on noin $35 \mathrm{~g} / 100 \mathrm{~g}$ ), josta noin 15 miljoonaa kiloa on korkeariskistä materiaalia ja tuhotaan polttamalla (Salminen 2002). Suomessa lannoitteissa myytiin $2009154 \times 10^{6} \mathrm{~kg} \mathrm{~N}$ ja 12 x $10^{6} \mathrm{~kg}$ P. Jos kaikki eläinperäiset sivutuotteet käytettäisiin lannoitteiksi, lukuun ottamatta korkeariskisiä sivutuotteita, niin voitaisiin vähintään $6 \%$ typestä ja $50 \%$ fosforista, jotka väkilannoitteet sisältävät, korvata sivutuotteiden ravinteilla.

Lihaluujauhoa on tutkittu ennen tämän oman työmme (Chen et al. 2011) julkaisemista viime vuosina lähinnä viljojen lannoitteena. Jengin et al. $(2004,2006)$ tulosten mukaan lihaluujauho oli tehokas vehnän ja ohran lannoite. Salomonsson et al. $(1994,1995)$ tutkivat lihaluujauhon vaikutusta jyväsadon valkuaispitoisuuteen kevät- ja syysvehnällä. Heidän tuloksissaan lihaluujauhon typen käyttökelpoisuus oli samanlainen kuin urean. Lihaluujauholannoituksen vaikutus vehnän leivontaominaisuuksiin oli sama kuin väkilannoituksen (Fredriksson et al. 1995). Lihaluujauholannoituksella voitiin myös torjua perunaruttoa ja perunaankeroista (Lazarovits et al. 1999).

Lihaluujauhon fosforin (P) käyttökelpoisuutta on myös tutkittu. Lihaluujauhon P on suurimmaksi osaksi kalsiumiin sidottuna apatiittina luuaineksessa, osa on orgaanisessa muodossa lihaosassa (Jeng et al. 2006). Maan happamuus vaikuttaa lihaluujauholannoituksen fosforin käyttökelpoisuuteen. Yliavainio et al. (2007) totesivat, että $90 \%$ lihaluujauhon fosforista liukeni suolahappoon (1 M HCl). Lihaluujauhon fosforilla onkin viljelymaassa jälkivaikutus: lihaluujauhon P säilyy maassa käyttökelpoisessa muodossa, ja vapautuu hitaasti vähintään kolmen vuoden ajan happamassa maassa, ja kun $\mathrm{pH}$ on yli 6,5 , huomattavasti kauemmin. Ohran ja rypsin viljelyssä lihaluujauhon fosforin lannoitusvaikutus oli selvästi tehokkaampi kuin raakafosfaatin (Bekele ja Höfner 1993).

Tämän tutkimuksen tavoitteena oli selvittää orgaanisen lihaluujauhon lannoitusvaikutus viljan sadon määrään ja laatuun verrattuna väkilannoitteeseen. Tavoitteena oli lisäksi todeta, miten lannoituksen määrä erityisesti typen annoksen osalta vaikuttaa lihaluujauhon ja väkilannoitteen vertailun tulokseen. Tutkimuskasveiksi valittiin ohra ja kaura, jotka ovat Suomessa laajalti viljelyssä.

\section{Aineisto ja menetelmät}

Tutkimus tehtiin Maa- ja elintarviketalouden tutkimuskeskuksen Etelä-Pohjanmaan tutkimusasemalla Ylistarossa vuosina 2000-2003. Sääolosuhteet olivat koevuosina alueelle tyypilliset (taulukko 1), vain vuoden 2001 toukokuu oli selvästi kylmempi ja sateisempi kuin tavallisesti. Koepaikan maa oli vähän (3-6 \%) eloperäistä ainesta sisältävää hiesuista hietaa (taulukko 2).

Tutkimuksessa ohralajikkeena käytettiin monitahoista Thulea ja kauralajikkeena oli vuosina 2000 ja 2001 Veli, ja vuosina 2002 ja 2003 Belinda. Siemen oli peittaamatonta, mutta muuten käytettiin tavanomaisessa viljelyssä tyypillistä viljelytekniikkaa kasvinsuojeluineen (herbisideinä Express Classic ja Starane). Väkilannoitteena käytettiin Pellon Y3 (20-3-9) - lannoitetta, joka pääravinteiden lisäksi sisältää 0,5 \% $\mathrm{Mg}, 3,0 \% \mathrm{~S}, 0,02 \%$ B ja 0,0015 \% Se. Honkajoki Oy toimitti kokeessa käytetyn lihaluujauhon (7-5-1), jonka analyysitiedot esitetään taulukossa 3 .

Tutkimus tehtiin täydellisesti satunnaistettuna osaruutukokeena, jossa oli neljä kerrannetta. Pääruudun tekijänä oli lannoitusmäärä, ja tutkimuksessa lannoitteita käytettiin kokonaistypen mukaan määriteltyinä 60,90 tai $120 \mathrm{~kg} / \mathrm{N}$ ha. Muita ravinteita tuli lannoituksessa niiden sisältämien ravinteiden suhteessa, eikä kokeessa muiden ravinteiden määrää tasoitettu. Osaruutuna oli lannoitelaji. Järjestely salli testata lan- 
noitteen käyttömäärä x lannoitelaji - yhdysvaikutukset. Lisäksi tutkimuksessa oli mukana 0-ruutu joka kerranteeseen. Pääruutujen koko oli 2,2 m* $10 \mathrm{~m}$.

Tutkimus toteutettiin edellä kuvatun mukaisesti vuosina 2000-2002, siten että vuonna 2002 jatkui enää kaurakoe. Vuonna 2003 kauralle perustettu kenttä palveli lannoituskäsittelyiden jälkivaikutusten vertailua, edelleen kauralle kylvettynä. Esikasvina ohrakokeessa oli ruis ja kaurakokeessa ruis ja kevätvehnä.

Sato puitiin ja kuivattiin normaalisti ja satomäärä ilmoitettiin kiloina hehtaaria kohden $15 \%$ kosteudessa. Viljan laadusta tehtiin neljä eri määritystä: 1000 siemen paino, hehtolitrapaino, valkuaispitoisuus ja valkuaissato. Valkuaispitoisuus määritettiin Kjeldahl menetelmällä MTT:n Jokioisten laboratoriossa.

\section{Tulosten käsittely}

Varianssianalyysi tehtiin SPSS - ohjelman proseduurilla, joka sopi tutkimussuunnitelmaan. GLM toistettujen määritysten proseduuria käytettiin lineaaristen vastaavuuksien testaamisen täysin satunnaistetussa osaruutukokeessa. Vuosivaikutus sisällytettiin osaruutukokeen tekijänä (Gomez \& Gomez 1984), kun käsittely lannoitusmäärä x lannoitetyyppi oli kokeessa ohralla 2 vuotena ja kauralla 3 vuotena peräkkäin. Kun käsiteltiin 0-ruudun vertailua lannoitteisiin, käsiteltiin lihaluujauho- ja väkilannoitteiden vaikutukset erikseen täydellisesti satunnaistettuna kokeena pääruudun tasolla. Tällöin käytettiin Tukeyn testiä $5 \%$ riskitasolla.

Tutkimuksen tulosten perusteella laskettiin typen käytön tehokkuuskerroin (NUE \%) sen perusteella kuinka paljon lannoituksessa käytetystä typestä saatiin korjatussa sadossa. NUE määriteltiin seuraavan kaavan mukaisesti: NUE \% $=\mathrm{N}$ otto $\left(\mathrm{kg} \mathrm{ha}^{-1}\right)$ lannoitetuilla lohkoilla $-\mathrm{N}$ otto $\left(\mathrm{kg} \mathrm{ha}^{-1}\right) / \mathrm{N}$ käyttömäärä $(\mathrm{kg}$ $\left.\mathrm{ha}^{-1}\right)$.

\section{Tulokset}

\section{Sadon määrä}

Lihaluujauho antoi kaikilla typpiportailla tilastollisesti samansuuruiset ohra- ja kaurasadot kuin mineraalilannoite. Suurinta typpilannoitusmäärää ( $120 \mathrm{~kg} \mathrm{~N} / \mathrm{ha})$ vastaavilla lannoitusmäärillä ohran sato oli noin $4500 \mathrm{~kg} / \mathrm{ha}$ ja kauran sato noin $5000 \mathrm{~kg} / \mathrm{ha}$. Ohran sato kasvoi typpiportaittain lannoitusta lisättäessä, sato oli $60 \mathrm{~kg}$ /ha typpitasolla $3600 \mathrm{~kg}$ ja merkitsevästi suurempi, keskimäärin 4300 kg/ha, 90 ja 120 typpitasoilla siten, että jälkimmäisten välinen ero ei ollut tilastollisesti merkitsevä. Kauran sato ei kasvanut typpiportaittain. Keskimäärin lannoitettujen kauraruutujen sato oli $4900 \mathrm{~kg} / \mathrm{ha}$. Lannoittamattomaan kontrolliin verrattuna sekä ohra että kaura hyötyivät lannoituksesta merkitsevästi.

\section{Lannoituksen jälkivaikutus}

Vuoden 2003 tulosten mukaan kauran sato oli lihaluujauhon jälkivaikutuksella selvästi suurempi kuin väkilannoitteen jälkeen. Lihaluujauholla kolmena edellisenä vuotena lannoitetut lohkot tuottivat keskimäärin 381 kg enemmän satoa kuin PY3 - lannoitteella lannoitetut. Jälkivaikutusvuotena sato nousi, kun edellisinä vuosina oli käytetty enemmän lannoitusta, 60 kilon N-lannoituksen jälkivaikutuksella sato oli keskimäärin $1780 \mathrm{~kg}$ /ha, kun $120 \mathrm{~kg} \mathrm{~N}$-tasolla sato oli $2600 \mathrm{~kg} /$ ha. 0-ruudun jälkivaikutusvuoden sato oli noin 1800 $\mathrm{kg} / \mathrm{ha}$.

\section{Sadon laatuominaisuudet}

Lannoitteen määrä ja laatu eivät vaikuttaneet sadon tuhannen siemenen painoon merkitsevästi. Myöskään hehtolitrapainoon lannoitteen määrällä tai laadulla ei ollut mainittavaa vaikutusta, vain ohralla pienin lannoitusmäärä antoi merkitsevästi alemman hehtolitrapainon $(64,4 \mathrm{~kg} / \mathrm{hl})$ kuin kaksi suurempaa lannoitusmäärää $(65,5 \mathrm{~kg} / \mathrm{hl})$, lannoitelajista riippumatta.

Valkuaispitoisuus ei eronnut eri lannoitelaatujen välillä merkitsevästi, mutta lannoitteen määrän lisääntyessä nousi myös sadon valkuaispitoisuus ja erot olivat merkitseviä. Ohralla valkuaispitoisuus nousi 10,5\%:sta $60 \mathrm{~kg} \mathrm{~N}$-tasolla, 11,1\%:iin 90 kilon N -tasolla ja 11,9\%:iin $120 \mathrm{~kg}$ N-tasolla. 0-ruudussa valkuaispitoisuus oli 10,1\%. Kauralla lannoitteen lisääntynyt käyttömäärä nosti valkuaispitoisuutta 11,4\%:sta 12,2 \%:n kautta 13,1\%:iin typpilannoituksen ollessa 60, 90 ja $120 \mathrm{~kg} / \mathrm{ha} .0$-ruudun valkuaispitoisuus oli vain $10,8 \%$. Molemmilla lajeilla saatu proteiinisato ei siis eronnut merkitsevästi eri lannoitelajien välillä, mutta lannoitemäärän lisääminen nosti proteiinisatoa merkitsevästi.

\section{Typen käytön tehokkuus}

Typen käytön tehokkuus ei eronnut eri lannoitteilla sen paremmin ohralla kuin kaurallakaan merkitsevästi. 
Ohralla typen käytön tehokkuus vaihteli 9,2\%:sta 40,2 \%:iin ja kauralla 14,6 \%:sta 58,8 \%:iin. Typen käytön tehokkuuden erot eri typpilannoitusmäärien välillä eivät olleet johdonmukaisia vuosien tai lannoitusmäärien suhteen.

\section{Johtopäätökset}

Tutkimuksen tavoitteena oli selvittää lihaluujauhon soveltuvuus ohran ja kauran lannoitteeksi verrattuna tyypilliseen väkilannoitteeseen. Tutkimuksessa vertailtiin eri typpitasoja toisiinsa, mutta kun lannoitteita käytettiin eri määriä, myös muiden lannoitteissa annettujen ravinteiden määrät muuttuivat vastaavasti. Näin ollen tulokset eivät kerro vain lihaluujauhon typen käyttökelpoisuudesta, vaikka sen merkitys sadon määrän kannalta onkin suurin. Typen määrinä käytettiin lannoitteiden sisältämiä kokonaisravinteiden määriä, joka vääristää osaltaan tuloksia, koska lihaluujauhon typen käyttökelpoisuus ei ole täysin tunnettu. Kokeessa käytetty lihaluujauho sisälsi noin $7 \%$ typpeä (kokonaistyppi) ja noin 2,5\% ammoniumtyppeä, joka on liukoisuudeltaan keinolannoitteeseen verrattavaa.

Tässä tutkimuksessa, joka tehtiin yhdellä koepaikalla 4-vuoden aikana vuosina 2000-2003, lihaluujauhon lannoitusvaikutus ei eronnut väkilannoitteen (PY3) lannoitusvaikutuksesta ohralla ja kauralla. Tulos vastaa Ruotsissa syys- ja kevätvehnällä saatuja tuloksia (Salomonsson et al. 1994, 1995). Ensimmäisenä koevuotena lihaluujauhon käyttömäärän nostaminen 857 kilosta $(60 \mathrm{~kg} \mathrm{~N} / \mathrm{ha}) 1714$ kiloon (120 kg N/ha) ei nostanut ohran tai kauran satoa, mutta samalla koepaikalla seuraavana vuonna sato nousi merkitsevästi lannoitemäärän noustessa. Mahdollinen selitys voisi olla edellisestä vuodesta jääneiden liukoisten ravinteiden vaikutus. Lundström ja Lindén (2001) totesivat, että jos esikasvi oli jättänyt maahan runsaasti kasveille käyttökelpoista typpeä, jo $40 \mathrm{~kg}$ lihaluujauhon typpeä riitti tuottamaan normaalin satomäärän. Jeng et al. (2006) totesi ohrakokeessa, että $500 \mathrm{~kg}$ lihaluujauhoa (8-6) riitti tuottamaan hyvän sadon eikä satomäärä noussut vaikka lannoitemäärää lisättiin. Kuten väkilannoitteilla lannoitettaessa, myös lihaluujauholannoituksen vaikutus luonnollisestikin riippuu maassa ennestään liukoisena kasvin ulottuvilla olevien ravinteiden määrästä.

Lihaluujauhon keskimääräinen $\mathrm{C} / \mathrm{N}$-suhde on 3-4 (Jeng et al. 2004), joka on edullinen mikrobiologisen mineralisoitumisen kannalta. Typen nopean mineralisaation lihaluujauhosta ovat osoittaneet Chaves et al. (2005) ja Mondini et al. (2008). Toisaalta Jengin et al. (2004) tutkimuksessa pieni lihaluujauhon käyttömäärä ( $60 \mathrm{~kg} \mathrm{~N} / \mathrm{ha}$ ) aiheutti typen nopean sitoutumisen maahan pian itämisen jälkeen. Kun lannoitteen käyttömäärät olivat suurempia, ravinteiden sitoutumisella ei ollut suurta vaikutusta kasvien typen ottoon. Kokeessa käytetyssä lihaluujauhossa oli $7 \%$ typpeä, josta 2,5 \% oli ammoniumtyppeä ja loput 4,5\% oli sitoutuneena orgaaniseen ainekseen.

Lihaluujauholla on myös merkittävä fosforilannoitusvaikutus. Ylivainio et al. (2007) huomasivat, että vaikka lihaluujauhon fosfori on pääosin happoon liukenevassa muodossa, se voi maassa muuttua kasveille käyttökelpoiseksi. Ensimmäisenä vuotena lihaluujauholannoituksen fosforista vain $19 \%$ tuli kasvien käyttöön, mutta kolmantena vuotena sen fosforilannoitusvaikutus raiheinällä oli yhtä suuri kuin karjanlannan tai superfosfaatin fosforilla (Ylivainio et al. 2007). Lihaluujauho ei ole vain ravinnepitoinen lannoite, vaan lisäämällä maaperän pieneliöstön toimintaa se toimii myös maanparannusaineena (Mondini et al. 2008). Kahiluodon ja Vestbergin (1998) tutkimuksen mukaan lihaluujauho lisäsi arbuskelimykorritsan aktiivisuutta kuten karjanlantakin, kun taas väkilannoitteet vähensivät sitä.

Lihaluujauhon jälkivaikutus kauran sadon määrään lannoituskäyttöä seuraavana vuotena oli parempi kuin väkilannoitteella. Kuitenkin vain korkeimman lannoitustason jälkivaikutus erosi merkitsevästi 0ruudusta. Hitaasti liukeneva fosfori, orgaanisen typen kertyminen ja mikrobiologisen aktiivisuuden lisääntyminen voisivat selittää jälkivaikutuksen eron väkilannoitteeseen. Tämän asian selvittämiseen tarvittaisiin kuitenkin lisää tutkimusta.

Laatuvaikutusten suhteen lihaluujauho ei eronnut merkitsevästi väkilannoitteesta. Edes valkuaispitoisuus, joka riippuu voimakkaasti kasvin typen saannista, ei eronnut eri lannoitteiden välillä. Tulokset ovat samankaltaisia kuin Salomonsson et al. $(1994,1995)$ ja Fredriksson et al. $(1997,1998)$ vehnäsadon laatuominaisuuksia tutkiessaan saivat. Valkuaispitoisuus ja valkuaissato kasvoivat lannoituksen lisääntyessä niin lihaluujauholla kuin väkilannoitteellakin.

Lihaluujauhon N/P -suhde on kasvien ravinnetarpeeseen nähden väärä, koska suurin osa kasveista ottaa N/P ravinteita suhteessa 4,5 -9, ja siksi jatkuva lihaluujauholannoitus voi johtaa fosforin kertymiseen maahan. Lihaluujauhon fosforista on Ylivainion et al. (2007) mukaan lannoitusvuotena kuitenkin käyttökelpoista korkeintaan $20 \%$. Siitä laskettuna lihaluujauhon välittömästi käyttökelpoisten ravinteiden N/P on 
noin 8 , joka on hyvin lähellä kasvien käyttämien ravinteiden suhteita. Siksi lihaluujauho voisi olla hyvä perustamislannoitus monivuotisille kasveille ja nurmille, koska sen fosfori vapautuu vasta vuosien kuluessa.

Jeng ja Vagstad (2008) totesivat että lihaluujauhon ravinteista merkittävä osa, erityisesti typpeä ja fosforia, voi huuhtoutua hyvin aikaisessa kevätlevityksessä. Lihaluujauhoa kannattaa käyttää lannoittamalla kylvön yhteydessä joko maahan sijoittaen tai juuri ennen kylvöä maahan muokattuna. Näin lannoitteen ravinteet saadaan käytettyä mahdollisimman tehokkaasti hyväksi, ja samalla vähennetään ympäristön kuormitusta.

EFPRA:n (European Fat Processors and Renderers Association) mukaan yhä edelleen merkittävä osa lihaluujauhosta tai sen raaka-aineista eläinperäisistä sivutuotteista poltetaan tai käsitellään kaatopaikoilla Euroopassa. Yli 70 \% kaikista eläinperäisistä sivutuotteista on joko riskitöntä (elintarvikekäyttöön sopivaa) tai matalariskistä materiaalia, josta valmistettua lihaluujauhoa saa käyttää lannoitteena tai lannoitteen raaka-aineena.

Tämän tutkimuksen perusteella lihaluujauho on tehokas lannoite, joka kannattaa käyttää hyödyksi ja näin palauttaa ruokajärjestelmässä muuten hyödyntämättömät ravinteet pelloille lannoitteeksi. Suosittelemme, että lihaluujauhosta valmistetaan granuloitua seoslannoitetta. Käyttämällä siihen muita elintarviketeollisuuden sivutuotteita saadaan lannoitteen ravinnesuhteet vastaamaan paremmin kasvien tarpeita. Tuotekehitykseen tulisi seuraavaksi panostaa.

\section{Kirjallisuus}

Bekele, T. \& Höfner, W. 1993. Effects of different phosphate fertilisers on yield of barley and rape seed on reddish brown soils of the Ethiopian highlands. Nutrient Cycling in Agroecosystems 34: 243-250.

Brewer, M.S. 1999. Current status of bovine spongiform encephalopathy - A review. Journal of Muscle Food 10: 97117.

Chaves, C., Canet, R., Albiach, R., Marin, J., Pomares, F., 2005. Meat and bone meal: fertilizing values and rates of nitrogen mineralization. In: Bernal, M.P., Moral, R., Clemente, R., Paredes, C. (Eds.), Proceedings of the 11th International Conference RAMIRAN, Murcia, Spain, vol. 1, 6-9 October 2004, pp. 177-180.

Chen, L., J. Kivelä, J. Helenius \& A. Kangas 2011. Meat bone meal as fertilizer for barley and oat. Agricultural and Food Science 20: 235-244.

FAO 2006. World reference base for soil resources 2006. A framework for international classification, correlation and communication. 103 p. Food and Agriculture Organization of the United Nations, Rome.

Fredriksson, H., Salomonsson, L. \& Salomonsson, A. 1997. Wheat cultivated with organic fertilisers and urea: baking performance and dough properties. Acta Agriculturae Scandinavica Section B-Soil Plant Science 47: 35-42.

Fredriksson, H., Salomonsson, L., Andersson, R., Salomonsson, A. 1998. Effects of Protein and Starch Characteristics on the Baking Properties of Wheat Cultivated by Different Strategies with Organic Fertilisers and Urea. Acta agricultura Scandinavica. Section B, Soil and plant science 48: 49.

Frosch, R.A. \& Gallopoulos, N.E. 1989. Strategies for manufacturing. Scientific American 261: 144-152.

Gomez, K. A. \& Gomez, A. A. 1984. Statistical Procedures in Agricultural Research, 2nd edition. 680 p. New York, Wiley

Graedel, T.E. 1996. On the concept of industrial ecology. Annual Review of Energy and Environment 21: 69-98.

Jeng, A., Haraldsen, T.K., Vagstad, N. \& Grønlund, A \& Tveitnes, S. 2004. Meat and bone meal as nitrogen fertiliser to cereals in Norway. Agricultural and Food Science 13: 268-275.

Jeng, A.S., Haraldsen, T.K., Grønlund, A. \& Pedersen, P.A. 2006. Meat and bone meal as nitrogen and phosphorus fertiliser to cereals and rye grass. Nutrient Cycling in Agroecosystems 76: 183-191.

Jeng, A.S., Vagstad, N. 2008. Potential nitrogen and phosphorus leaching from soils fertilized with meat and bone meal. Acta Agriculturae Scandinavica, Section B-Plant Soil Science 59: 1-8.

Kahiluoto, H. \& Vestberg, M. 1998. The effect of arbuscular mycorrhiza on biomass production and phosphorus uptake from sparingly soluble sources by leek (Allium porrum L.) In Finnish field soils. Biological Agriculture and Horticulture 16: 65-85.

Lazarovits, G., Conn, K. \& Potter, J. 1999. Reduction of potato scab, Verticillium wilt, and nematodes by soymeal and meat and bone meal in two Ontario potato fields. Canadian Journal of Plant Pathology 21: 345-353

Lundström, C. \& Lindén, B. 2001. Nitrogen effects of human urine, meat bone meal (Biofer) and chicken manure (Binadan) as fertilisers applied to winter wheat, spring wheat, and spring barley in organic farming. Swedish University of Agricultural Sciences, Department of Agricultural, Skara, Series B crops and soils, report 8:51.

Mondini, C., Cayuela, M.L., Sinicco, T., Sanchez-Monedero, M., Bertolone, E. \& Bardi, L. 2008. Soil application of meat and bone meal. Short-term effects on mineralization dynamics and soil biochemical and microbiological properties. Soil Biology \& Biochemistry 40: 462-474.

Peltovuori, T. 1999. Precision of commercial soil testing practice for phosphorus fertilizer recommendations in 
Finland. Agricultural and Food Science in Finland 8: 299-308.

Salomonsson, L., Jonsson, A., Salomonsson, A. \& Nilsson, G. 1994. Effects of organic fertilisers and urea when applied to spring wheat. Acta agriculturce Scandinavica. Section B, Soil and plant science 44: 170.

Salomonsson, L., Salomonsson, A., Olofsson, S. \& Jonsson, A. 1995. Effects of organic fertilisers and urea when applied to winter wheat. Acta agricultura Scandinavica. Section B, Soil and plant science 45: 171.

Salminen, E. 2002. Finnish expert report on best available techniques in slaughterhouses and installations for the disposal or recycling of animal carcasses and animal waste. The Finnish Environment 539: 42.

Vuorinen, J. \& Mäkitie, O. 1955. The method of soil testing used in Finland. Agroecological publications 63:1-14.

Werner, W. 2003. Complementary nutrient sources. In: IFA-FAO Agriculture Conference Global Food Security and the Role of Sustainable Fertilisation, Rome, 26-28 March 2003.

Yli-Halla, M., Mokma, D., Peltovuori, T. \& Sippola, J. 2000. Suomalaisia maaprofiileja (Abstract: Agricultural soil profiles in Finland and their classification). Maatalouden Tutkimuskeskuksen Julkaisuja, Sarja A 78.104 p.

Ylivainio, K., Uusitalo, R. \& Turtola, E. 2007. Meat bone meal and fox manure as P sources for ryegrass (Lolium multiflorum) grown on a limed soil. Nutrient Cycling in Agroecosystems, 81:267-278.

Taulukko 1. Lämpötila ja sademäärä kasvukausilla 2000 - 2003. Vertailuaineistona Ylistaro 1960-91.

\begin{tabular}{lllllllllll}
\hline \multicolumn{1}{c}{ Keskilämpötila $\left({ }^{\circ} \mathrm{C}\right)$} & \multicolumn{7}{c}{ Sademäärä $(\mathrm{mm})$} \\
& 2000 & 2001 & 2002 & 2003 & $1960-91$ & 2000 & 2001 & 2002 & 2003 & $1960-91$ \\
\hline Touko & 10.3 & 7.6 & 11.3 & 9.7 & 8.8 & 36.9 & 89.2 & 44.4 & 69.5 & 38 \\
Kesä & 13.9 & 14.2 & 15.8 & 13.1 & 14.0 & 38.5 & 63.0 & 64.2 & 68.2 & 42 \\
Heinä & 16.1 & 17.6 & 18.1 & 19.5 & 15.5 & 75.2 & 61.4 & 82.3 & 72.3 & 68 \\
Elo & 13.9 & 14.5 & 17.7 & 14.3 & 13.6 & 77.6 & 79.4 & 56.6 & 31.2 & 70 \\
\hline K.a. & 13.6 & 13,5 & 13.5 & 14.2 & 13.0 & 228 & 293 & 247 & 241 & 218 \\
\hline
\end{tabular}

Taulukko 2. Maan pH ja ravinnetilanne ennen kokeen aloitusta vuonna 2000.

\begin{tabular}{|c|c|c|c|c|}
\hline & Ohran lannoituskoe & Määritelmä & Kauran lannoituskoe & Määritelmä \\
\hline $\mathrm{pH}$ & 5.8 & tyydyttävä & 5.4 & välttävä \\
\hline $\mathrm{Ca}, \mathrm{mg} \mathrm{l}^{-1}$ & 726 & välttävä & 728 & välttävä \\
\hline $\mathrm{P}, \mathrm{mg} \mathrm{l}^{-1}$ & 7.0 & tyydyttävä & 5.5 & tyydyttävä \\
\hline $\mathrm{K}, \mathrm{mg} \mathrm{l}^{-1}$ & 131 & kohtalainen & 113 & tyydyttävä \\
\hline $\mathrm{Mg}, \mathrm{mg} \mathrm{l}^{-1}$ & 173 & kohtalainen & 144 & kohtalainen \\
\hline
\end{tabular}

Taulukko 3. Lihaluujauhon sisältämät ravinteet ja raskasmetallit Honkajoki Oy:n teettämän analyysin mukaan.

\begin{tabular}{llllll}
\hline Pääravinteet & $\%$ & Hivenravinteet & $\mathrm{mg} / \mathrm{kg}$ & Raskasmetallit & $\mathrm{mg} / \mathrm{kg}$ \\
\hline $\mathrm{N}$ & 7.0 & $\mathrm{~B}$ & 25 & $\mathrm{~Pb}$ & 0.50 \\
$\mathrm{~N}$ vs & 2.5 & $\mathrm{Co}$ & 0.15 & $\mathrm{Cd}$ & 0.1 \\
$\mathrm{P}$ & 5 & $\mathrm{Cu}$ & 3.9 & $\mathrm{Hg}$ & 0.01 \\
$\mathrm{P}$ vs & 0.15 & $\mathrm{Fe}$ & 58 & $\mathrm{Ni}$ & 0.55 \\
$\mathrm{~K}$ & 1 & $\mathrm{Mn}$ & 4 & & \\
$\mathrm{Ca}$ & 12.0 & $\mathrm{Zn}$ & 55 & & \\
$\mathrm{Mg}$ & 0.8 & $\mathrm{Se}$ & 0.19 & & \\
$\mathrm{~S}$ & 0.5 & & & & \\
$\mathrm{Na}$ & 0.5 & & & & \\
\hline
\end{tabular}

